\title{
Severe crush injury to the lower extremity after a snowmobile accident in rural Greenland
}

\author{
Anne Kathrine Lorentzen, ${ }^{1}$ Luit Penninga ${ }^{2}$
}

'Ilulissat Hospital, Ilulissat, Greenland

${ }^{2}$ Avannaa Health Region, Ilulissat Hospital, Ilulissat, Greenland

\section{Correspondence to}

Dr Luit Penninga,

Luitpenninga@hotmail.com

Accepted 7 October 2017

\section{DESCRIPTION}

In Arctic Greenland, the traditional transportation method of dogsledding is increasingly being replaced by snowmobiles. Snowmobile-related injuries and fatalities are increasing, causing 281 hospitalisations yearly in Wisconsin alone. ${ }^{1}$ Injuries often include musculoskeletal damage. ${ }^{2}$ Greenland is a vast country spanning $2,600 \mathrm{~km}$ from North to South, with extreme weather conditions making provision of healthcare a logistical challenge.

We present the case of a 24-year-old man involved in a high-speed snowmobile collision in rural Northern Greenland. Snowmobiling at night, his vehicle was impacted by another snowmobile, crushing his left lower extremity (figure 1). He was evacuated by helicopter more than $800 \mathrm{~km}$ south to Greenland's referral hospital in the capital city Nuuk for surgical care. The fracture was fixated externally with the Hoffman frame. The ruptured muscle and skin was sutured, leaving a $4 \mathrm{~cm}$ skin defect treated with negative pressure wound therapy. Due to subsequent tissue necrosis, he underwent six surgical revisions and received a skin autograft at 1.5 months post-injury. The external fixation was later replaced by an intramedullary nail. He was discharged after a total admission period of 2 months. He retained full motor and sensory function of his left extremity, and the skin grafting was successful (figure 2).

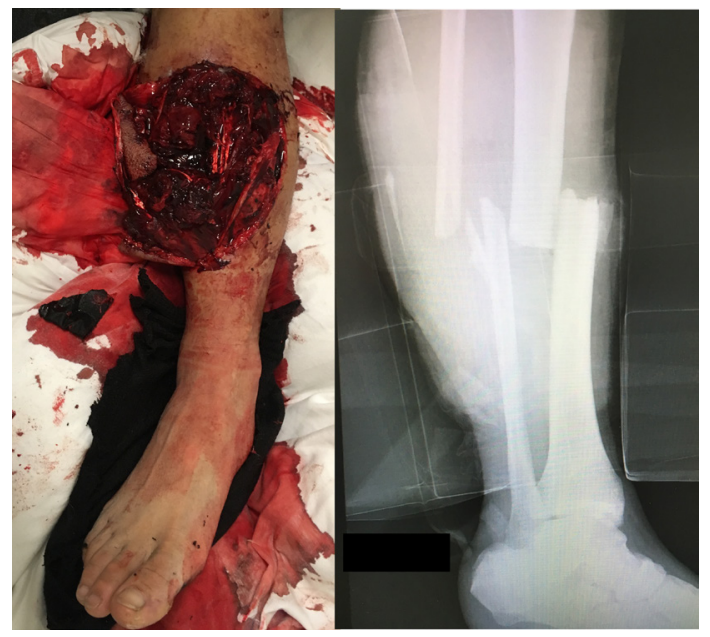

Figure 1 Open fracture of the left tibia and fibula, with significant damage to overlying skin and muscles (left). X-ray shows mid-shaft tibia and fibula fracture with limb shortening (right).

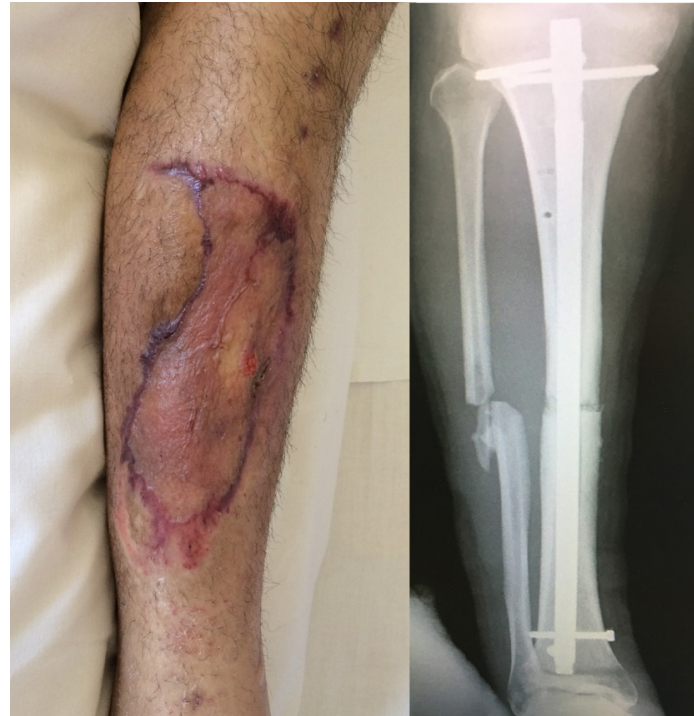

Figure 2 Successful skin grafting of the wound (left), and the Hoffman frame replaced with an intramedullary nail (right).

\section{Learning points}

Snowmobile accidents can cause severe injuries, which may lead to extensive morbidity and even death.

- Snowmobile injuries often include musculoskeletal damage, for example, fractures and soft-tissue lesions.

- Measures to prevent the increasing number of snowmobile accidents must be taken to reduce the number of severe injuries and fatalities.

In the Inuit community, the incidence of injuries related to snowmobiling is rising due to alterations in transportation habits. Preventive measures such as use of safety equipment and focus on safe driving behaviour are paramount to reducing snowmobile-related morbidity and mortality. ${ }^{3}$

Contributors AKL and LP had the idea for the paper. AKL drafted and revised the paper. LP edited and revised the paper.

Competing interests None declared.

Patient consent Obtained.

Provenance and peer review Not commissioned; externally peer reviewed

(C) BMJ Publishing Group Ltd (unless otherwise stated in the text of the article) 2017. All rights reserved. No commercial use is permitted unless otherwise expressly granted. 


\section{REFERENCES}

1 Sy ML, Corden TE. The perils of snowmobiling. WMJ 2005;104:32-4.

2 Stewart RL, Black GB. Snowmobile trauma: 10 years' experience at Manitoba's tertiary trauma centre. Can J Surg 2004;47:90-4.
3 Mehus G, Mehus AG, Germeten S, et al. Young people and snowmobiling in northern Norway: accidents, injury prevention and safety strategies. Rural Remote Health 2016:16:3713.

Copyright 2017 BMJ Publishing Group. All rights reserved. For permission to reuse any of this content visit http://group.bmj.com/group/rights-licensing/permissions.

BMJ Case Report Fellows may re-use this article for personal use and teaching without any further permission.

Become a Fellow of BMJ Case Reports today and you can:

Submit as many cases as you like

Enjoy fast sympathetic peer review and rapid publication of accepted articles

- Access all the published articles

Re-use any of the published material for personal use and teaching without further permission

For information on Institutional Fellowships contact consortiasales@bmjgroup.com

Visit casereports.bmj.com for more articles like this and to become a Fellow 